\title{
Clerical Exemption in Canon Law from Gratian to the Decretals
}

\author{
Anne J. Duggan*
}

The question of clerical exemption from secular judgment was a core constituent of the fierce dispute that set King Henry II of England against Archbishop Thomas Becket of Canterbury in 1163 and culminated in the latter's murder in Canterbury Cathedral in 1170. This paper traces the Roman origin of immunity, its confused treatment in Gratian's Decretum, and the working out of a reasonable modus vivendi through episcopal-papal consultation in the following eighty or so years.

Keywords: clerical exemption: origins, definition, restriction. Ad falsariorum. Si quis suadente. Papal judgments: Eugenius III, Alexander III, Lucius III, Urban III, Celestine III, Innocent III.

It is important to recognize that the institutional framework of the medieval Church in the Latin West was conditioned by the structures of the late Roman world, from which, especially in legal matters, it absorbed much of its language and the concept of ordo judiciarius - the due process of law. Bishops from the time of Emperor Constantine had their own audientia episcopalis, a court modelled on that of provincial governors. ${ }^{1}$ Its principal job was the maintenance of ecclesiastical discipline as defined in Church assemblies from the Council of Arles (314) onwards, but it also dealt with disputes between ecclesiastical persons and entities and could, at the wish of the litigants, take cognizance of injuria (delicts) alleged by lay and clerical persons using a summary process ${ }^{2}$. Such courts were instructed to follow civil procedure in the conduct of appeals. ${ }^{3}$

Furthermore, the position of the Church in the civil order was recognized by imperial laws in the Theodosian Code (issued in 438) ${ }^{4}$ and especially in Emperor Justinian's Corpus iuris (issued in 533-534), where the second section of Book 1 of the Codex was devoted to »the sacrosanct churches and their properties and privileges. $\aleph^{5}$ Religious and sanctified things

* Correspondence details: Anne Duggan, Department of History, King's College London, Strand, London, WC2R 2LS, UK. Email: anne.duggan@kcl.ac.uk.

1 Gaudemet, Formation du droit séculier, 230, 498.

2 Justinian, Novellae, 83.1pr; Authenticum, ed. Haenel, 84.1pr: si quis habet adversus eos [bishops, priests, monks] quamlibet pecuniariam causam, prius ad deo amabilem episcopum pergat sub quo constitutus est, et interpellet eum et ex non scripto iudicium mereatur, Et si hoc fiat, nec inquietet eum nec trahat ad auditoria civilia neque a sacro eum vacare faciat ministerio, sed ex non scripto et examinetur negotium sine damnis et accipiat formam forsan etiam scriptam, si hoc quoque partes voluerint et poposcerint, et liberentur alterutro certamine. Cf. Gratian, C.11 q.1 c.45: Ubi autem dirimere episcopus uult, sine scriptura omnia procedant, et diffinitiva sententia ab eo sine scripturis feratur.

3 Codex Theodosianus, ed. Krueger, 16.2.23: Qui mos est causarum civilium, idem in negotiis ecclesiasticis obtinendus est; cf. Jasper, Beginning of the Decretal Tradition, 7-9.

4 Codex Theodosianus, ed. Krueger, 16.2.12; 16.2.47§1.

5 Codex Theodosianus, ed. Krueger, 1.2: De sacrosanctis ecclesiis et de rebus et privilegiis earum. 
(res religiosae ${ }^{6}$ sanctae $^{7}$ ) were under divine law (divini iuris est: Institutes 2.1.7), and sacred things (res sacrae) - churches and gifts dedicated to the service of God by bishops (pontifices) - were specially protected. Even if the church falls down, the ground remains sacred. ${ }^{8}$ In the first chapter of Justinian's Novel 86 (AD 539), which deals with co-operation between bishops and provincial judges in the delivery of justice, bishops were sbeloved of God` (deo amabilis) and most sanctified (sanctissimus), and they were frequently called >most religious (religiosissimus) in the Codex. ${ }^{9}$ The whole clerical establishment (bishops, priests, deacons, subdeacons, and the minor clerics of acolyte, exorcist, lector and porter), ${ }^{10}$ together with the growing ascetic and monastic orders (anchorites, monks, and nuns), was protected by the law, its property declared inalienable ${ }^{11}$ and inviolate: ${ }^{12}$

Those things which belong to the right of the most holy church, or shall later come to it, should, like that sacrosanct and religious Church itself, be reverently preserved inviolate (intacta).

Its churches were places of sanctuary; ${ }^{13}$ its sacred vessels protected, ${ }^{14}$ and serious assaults on its priests and ministers were prosecuted as public crimes..$^{15}$ Moreover they all enjoyed judicial privilege, defined in Justinian's Novel 83, issued in 539, based on the Roman principle that in civil matters (disputes between private persons, including causae pecuniariae: debts, damages, fines) a person should be judged by his own judge. This meant that clerics,

6 Justinian's Institutes, trans. Birks and McLeod, 2.1.9: res religiosae included tombs and burial grounds.

7 Justinian's Institutes, trans. Birks and McLeod, 2.1.10: "Sanctified things - res sanctae (city walls and gates) - are also in a certain sense under divine law: they cannot become private property. We call them sanctified because anyone who offends against them faces a capital penalty. « Sanction' refers to punishments specified by the law.

8 Justinian's Institutes, trans. Birks and McLeod, 2.1.8; cf. 1.2.21-23.

9 Novellae constitutiones, ed. Krueger, 86.1 and 3. Where the provincial judge does not dispense justice to a litigant, the bishop is to intervene; if that fails, he can send litigants to the emperor with letters explaining the matter, so that the emperor can deal with the judge. Codex Iustinianus, ed. Krueger, 1.2.16pr; 1.3.26, 28.2, 54.11, etc.

10 A schedule of clerics attached to the Roman church under Cornelius (251) lists 46 priests, 7 deacons, 7 subdeacons, 42 acolytes, and 52 >lesser clerics‘; cf. Codex Iustinianus, ed. Krueger 1.3.6: Presbyteros diaconos subdiaconos atque exorcistas et lectores, ostiarios.

11 Codex Iustinianus, ed. Krueger, 1.2.14pr, $\S \S 1,3,4$, 5, etc.; 1.2.22pr.

12 Codex Iustinianus, ed. Krueger, 1.2.14§2.

13 Codex Iustinianus, ed. Krueger, 1.12.o: De his qui ad ecclesias confugiunt vel ibi exclamant, esp. 1.12.2: nemini licere ad sacrosanctas ecclesias confugientes abducere: sub hac videlicet definitione, ut, si quisquam contra hanc legem venire temptaverit, sciat se ad maiestatis crimen esse retinendum (AD 409); cf. Codex Iustinianus, ed. Krueger,1.13.0. De his qui in ecclesiis manumittuntur.

14 Codex Iustinianus, ed. Krueger, 1.2.21pr (Justinian, 529); although they could be sold or pledged for the redemption of captives: $1.2 .21 \S 2$.

15 Codex Iustinianus, ed. Krueger, 1.3.10§1 (AD 398): atroces sacerdotibus aut ministris iniurias veluti publicum crimen persequi ac de talibus reis ultionem mereri. 
anchorites, monks, and nuns were subject to the audientia episcopalis, ${ }^{16}$ and lay people were subject to its jurisdiction in religious matters. Episcopal jurisdiction was seen as part of the imperial system of law; bishops co-operated with their secular counterparts in dispensing justice, although that did not make them civil judges. ${ }^{17}$ On the other hand, breaches of the public (criminal) laws were determined by the public judges according to those laws, but severe penalties could not be imposed on ordained clerics until the bishop had deprived them of their clerical status. ${ }^{18}$

Preserved and transmitted in the enucleated compilations which constituted the Theodosian Code and the Justinian Corpus iuris, these are the deep roots of the privilegium fori or 'privilege of the forum/court،, which protected clerics and religious from secular judgment in the Middle Ages. The Parisian theologian Hugh of St-Victor explained its practical effects in his treatise on the sacraments in the mid-1130s: ${ }^{19}$

For example, a secular judge is allowed to lay hands on a layperson if he sins, not on a cleric. [...] Secular matters should be examined by the secular power; spiritual and ecclesiastical matters by the spiritual power. [...] In regard to the person, then, justice is violated if a secular judge lays hands on an ecclesiastical person.

The phrase slay hands on (manum mittere) c carried special significance. It denoted a physical assault on the protected body of the cleric, here extended to all secclesiastical persons<, including monks and nuns, but it did not include civil procedures, in which there was no arrest, no seizure, and no imprisonment pending trial.

As the leading theologian of his generation, Hugh's teaching reached a wide audience, but his contemporary, Master Gratian, the founder of the school of canon law in Bologna, provided a much more comprehensive examination of the privilegium fori in his ground-breaking Concordia discordatium canonum (Concordance of discordant canons), popularly known as

16 Codex Iustinianus, ed. Krueger, 1.4.0: De episcopali audientia et de diversis capitulis, quae ad ius curamque et reverentiam pontificalem pertinent; cf. Council of Chalcedon (451), c.9: Liber Extra, ed. Friedberg, 2.2.1: Si quis clericus adversus clericum negotium habeat, non deserat episcopum proprium, et ad saecularia percurrat iudicia, sed prius apud ipsum actio ventiletur, vel certe consilio eiusdem episcopi apud alios, quos utraque pars voluerit, iudicium obtinebunt. Cf. Nov. 83pr (Authenticum., ed. Haenel, 84pr): si quis habet adversus eos quamlibet pecuniariam causam, prius ad deo amabilem episcopum pergat sub quo constitutus est, et interpellet eum et ex non scripto iudicium mereatur. Et si hoc fiat, nec inquietet eum nec trahat ad auditoria civilia neque a sacro eum vacare faciat ministerio, sed ex non scripto et examinetur negotium sine damnis et accipiat formam forsan etiam scriptam, si hoc quoque partes voluerint et poposcerint, et liberentur alterutro certamine.

17 Caroline Humfress has recently (2011) described the Church ras a fundamental part of late Roman dispute processing, although she does not draw a direct line of development from this episcopal jurisdiction to the later privilegium fori: Bishops and Law Courts in Late Antiquity, at 377 and 380.

18 Novellae, 83pr, §2; Authenticum, ed. Haenel, 84pr, §2: Si tamen de criminibus conveniantur, si quidem civilibus, hic quidem competentes iudices, in provinciis autem harum praesides sint iudices, non transcendente lite mensium duorum spatium ex quo litis contestatio fit, quatenus brevis imponatur causas terminus. Illud palam est, si reum esse putaverit eum qui convenitur provinciae praeses et poena iudicaverit dignum, prius hunc spoliari a deo amabili episcopo sacerdotali dignitate, et ita sub legum fieri manu. Cf. Gratian, C.11 q.1 c. $45 \S 1$.

19 De sacramentis, Part 2, c.8 (PL, clxxvi, 420-421): [...] quemadmodum saeculari judici in personam laicam si peccaverit manum mittere licet, in clericum non licet. [...] negotia saecularia a potestate terrena; spiritualia vero et ecclesiastica a spirituali potestate examinentur. [...] Secundum personam ergo justitia violaretur si judex saecularis in ecclesiasticam personam manum mitteret. 
the Decretum (vulgate edition, 1140-1145). This was a systematic compilation of ecclesiastical law, in three books, designed to underpin the study and application of the law of the Western Church. ${ }^{20}$ Its defining features were its inclusion of segments of Justinianic law, especially relating to judicial process, and its adoption, particularly in Part II, of the dialectical technique of argumentation, in which authorities were organized pro and contra around thirty-six major cases, including, for example, marriage (causae 27-36). Each case was divided into problems (questiones), in which the relevant authorities were set out in individual segments (capitula), and accompanied by the Master's own dicta (pronouncements), which attempted to resolve any contradictions. No fewer than fifty chapters in Causa 11, questio 1 deal with the matter of clerical immunity. ${ }^{21}$ Broadly, and based on the concept that each has his own court (forum), Gratian assembled the canons to demonstrate that clergy and laity belonged to separate but not mutually exclusive jurisdictions. In a (civil) dispute between a lay person and a cleric, or vice versa, the dispute should be determined in the court of the defendant according to the Roman legal principle that the plaintiff should seek redress in the defendant's court (actor forum rei sequatur). ${ }^{22}$ This meant that clergy should not be summoned before lay courts either by other clergy or by laymen; ${ }^{23}$ but where a cleric wished to pursue a layman in a civil action, he had to sue in the layman's court. Gratian stated the principle of clerical judicial privilege trenchantly in his assertion before chapter 32 , which concludes: ${ }^{24}$

The drawing of a cleric before a civil judge is prohibited by the sacred canons and the external (forensibus $=$ secular) laws, both in civil and in criminal cases.

- a conclusion most memorably supported in c.5 $\$ 1$ by an extraordinary declaration of the judicial immunity of Christian bishops attributed to the emperor Constantine at the Council of Nicaea (325): "You can be judged by no-one, because we reserve you for the judgment of God alone..$^{25}$ The same quotation appears later in the Decretum in a passage attributed to >Pope Melciades (Melitiades 311-314), where it is followed by an even more extravagant statement of episcopal privilege: "For you have been called gods, and therefore you cannot be judged by men. ${ }^{26}$ Although derived from the ninth-century Pseudo-Isidore (in which

20 Decretum Gratiani, ed. Friedberg, in Corpus Iuris Canonici 1. It is not possible to review here the still lively debate about the authorship and dating of this work, which was ignited by Winroth's Making of Gratian's Decretum, but see Pennington's review in Speculum, lxxviii (2003) 293-297 and Wei, Later Development of Gratian's Decretum. For the mysterious Master Gratian, who may have finished his career as bishop of Chiusi in the mid-1140s, see Winroth, Where Gratian Slept; and Pennington, Biography of Gratian.

21 Cf. Duggan, Making Old Law >New<, nn. 19-60.

22 Gratian, C.11 q.1 c.15: rubric, derived ultimately from Codex Iustinianus, ed. Krueger, 3.19.3: Actor rei forum, sive in rem sive in personam sit actio, sequitur. sed et in locis, in quibus res propter quas contenditur constitutae sunt, iubemus in rem actionem adversus possidentem moveri; cf. ibid. 3.13.2. For a succinct summary, see Berger, Encyclopedic Dictionary of Roman Law, 476, s.v. >Forum׳.

23 Gratian, C.11 q.1 c.16.

24 Sacris enim canonibus et forensibus legibus tam in ciuili quam in criminali causa clericus ad ciuilem iudicem pertrahendus negatur.

25 Gratian, C.11 q.1 c.5 §1: Vos a nemine diiudicari potestis, quia ad Dei iudicium solius reseruamini.

26 Gratian, C.12 q.1 c.15: Vos ... reseruamini. Dii etenim uocati estis, et idcirco non potestis ab hominibus iudicari. 
genuine and false scanons earlier source in Rufinus of Aquileia's two-book addition (ix-x) to his summary Latin version (c. 402) of the Ecclesiastical History of Eusebius of Caesarea Maritima (c. 323): »For you have been given to us as gods by God, and it is not fitting that a man should judge gods«, followed by a quotation of Psalm 81 [82]. ${ }^{28}$

This broad consensus, however, was disturbed by four canons among the 50 arrayed in Causa 11, questio 1, which recorded what appeared to be forms of traditio curie, in which clerics were stripped of their immunity and transferred to another (secular?) court for punishment. ${ }^{29}$

The first, the >Pius canon`, Si quis sacerdotum, attributed to >Pope Pius`, reads, ${ }^{30}$

If any priest or any other cleric is disobedient to his bishop, or plots against him, or inflicts insult, false accusation, or abuse upon him, and can be convicted of it, as soon as he is deposed he is to be handed over to the curia (mox depositus curiae tradatur) and receive retribution for his wrongful act (et recipiat quod inique gessit) (Coloss. 3: 25).

The second, the >Fabian canon`, Statuimus, reads,

We decree that if any cleric is rebellious or plots against his bishop, having been removed from the clergy (submotus a clero) in the presence of the court (iudicium), let him be handed over to the curia (curiae tradatur), which he is to serve all the days of his life, and remain defamed without hope of restoration (et infamis absque ulla spe restitutionis permaneat). ${ }^{31}$

Both seem clear enough: in cases of violent rebellion against episcopal authority, a bishop can degrade the cleric and transfer him to a secular court for punishment. Unfortunately, neither text is what it appears to be. Far from being authentic decrees of Popes Pius I (c.AD 140-154) and Fabian (AD 236-250), the canons were sconfected in northern France in the ninth century and transmitted in the compilation which historians have dubbed PseudoIsidore, because it was attributed to a fictitious >Isidorus Mercator«. This `Isidorus«, in turn, was easily confused with the real Isidore of Seville (c.560-636), author of the Etymologiae, the early medieval equivalent of a general encyclopaedia, and so carried the authority of a great name.

27 Pseudo-Isidore, 248: Vos a nemine diiudicare potestis, quia solius Dei iuditio reservamini, dii etenim vocati estis. Idcirco non potestis ab hominibus iudicari; cf. PL, cxxx, 243. Pseudo-Isidore did not attribute this text to the supposititious pope. Under the title, De primitiva ecclesia et sinodo Nicena, it followed a letter from `Melchiades`. Gratian (or an intermediate source) mistakenly linked the two. For Pseudo-Isidore, see below at nn. 33-34.

28 Rufinus, Historia Ecclesiastica, 468: [...] Vos etenim nobis a Deo dati estis dii, et conveniens non est ut homo judicet deos; trans. Amidon, The Church History of Rufinus of Aquileia, 10.

29 Gratian, C.11 q.1 c. 18, the >Pius canon; c. 20, the `Gregorian` canon; c. 31, the 'Fabian canon; c. 45, Novellae, 83.1= Authenticum, ed. Haenel, 83.1. For the following, see Duggan, Thomas Becket, 50-54.

30 C.11 q.1 c.18, Si quis sacerdotum uel reliquorum clericorum suo episcopo inobediens fuerit, aut ei insidias parauerit, aut contumeliam, aut calumpniam, uel conuicia intulerit, et conuinci potuerit, mox depositus curiae tradatur, ret recipiat quod inique gessit< [St Paul, Coloss. 3: 25].

31 Gratian, C.11 q.1 c.31: Statuimus, ut, si quis clericorum suis episcopis infestus aut insidiator extiterit, mox ante examinatum iudicium submotus a clero curiae tradatur, cui diebus uitae suae deseruiat, et infamis absque ulla spe restitutionis permaneat. 
Until recently, the dating and context of Pseudo-Isidore were narrowed to 847-52, either in the entourage of the deposed Archbishop Ebbo of Reims or, more generally, among the opponents of the powerful Hincmar of Reims (845-882) who had supplanted Ebbo in $845 .{ }^{32}$ Klaus Zechiel-Eckes has proposed an earlier historical and geographical context in the defence of Archbishop Ebbo of Reims in the political crisis of 833 and the monastery of Corbie, directed by Paschasius Radbertus. ${ }^{33}$ The compilers' aim was to protect bishops and other ecclesiastical persons and institutions from secular abuse and confirm episcopal authority with an assemblage of authentic ancient canons, augmented by cleverly confected ijudgments attributed to early popes and councils.

Set in the context and purpose of their fabrication, it is highly unlikely that they were intended to subject priests and clerics to lay judgment and/or punishment. The key to understanding these texts is the interpretation of the Latin noun curia. This word had a wide lexical range in the Middle Ages. Niermeyer's dictionary of medieval Latin, for example, lists 21 meanings, ranging from law-court/tribunal to assembly, household, courtyard, and prison. ${ }^{34}$ In the 'Fabian canon<, certainly, curia implies something different from a judicial forum. Having been removed from the clergy in the presence of the (bishop's) court (iudicium) , the condemned cleric was to be handed over to the curia, sthere to serve all the days of his lifer. This implies transfer, not to another, possibly lay, court but to a form of servitude, in the bishop's household or administration, probably modelled on late Roman curial status, which itself was a form of enforced service of the local municipal authority (curia), originally imposed on certain categories of secular malefactors. ${ }^{35}$ A decree of the emperors Arcadius, Honorius and Theodosius at the end of the fourth century, transmitted in the Theodosian Code (438), had imposed such curial service as a penalty for degraded or renegade clergy: ${ }^{36}$

Let the curia immediately claim for itself ... any cleric whom the bishop judges unworthy of his office and segregates from the service of the Church [...].

Fuhrmann, Einfluss und Verbreitung, i, 193-196; Fuhrmann, Pseudo-Isidorian Forgeries, 135-195.

Zechiel-Eckes, Ein Blick in Pseudoisidors Werkstatt; Zechiel-Eckes, Auf Pseudoisidors Spur; Zechiel-Eckes, Fälschung als Mittel politischer Auseinandersetzung; Richter, Stufen pseudoisidorischer Verfälschung, at 36 n. 201. For an excellent summary of the present state of this complicated question, see Knibbs, Interpolated Hispana. Cf. Fried, Donation of Constantine, 101-103; Schieffer, Zeit des karolingischen Großreichs, 159.

34 Mediae Latinitatis lexicon minus, ed. Niermayer, i, 378A-381A.

35 Berger, Encyclopedic Dictionary of Roman Law, 612-613, s.v. >Ordo decurionum২, ad fin., "Under Justinian the curia became a kind of a penitentiary since the assignment to the curia was applied as a punishment.« Such a punishment was applied in Tuscany in the late eleventh century, where the curia concerned was the household/court of Countess Mathilda of Tuscany: Duggan, Becket Dispute, 12.

36 Codex Theodosianus, ed. Krueger, 16.2.39: Quemcumque clericum indignum officio suo episcopus iudicaverit et ab ecclesiae ministerio segregaverit, aut si qui professum sacrae religionis obsequium sponte dereliquerit, continuo eum curia sibi vindicet, ut liber illi ultra ad ecclesiam recursus esse non possit, et pro hominum qualitate et quantitate patrimonii vel ordini suo vel collegio civitatis adiungatur....; cf. Duggan: Becket Dispute, 8-10. 
It is likely that the forgers of the Pius and Fabian canons had this decree in mind when they constructed their own papal variant, but their curia was the curia episcopalis not the secular curia. In both cases, the convicted cleric is reduced to a form of penitential servitude in the bishop's household. The question of secular judgment or penalty did not arise. ${ }^{37}$

Support for this interpretation is found in the judgment given by Pope Gregory VII in a council in Rome (1079) against the canons of Lucca cathedral, who had rebelled against Bishop Anselm (1071, 1073-1083). Gregory's judgment was based on the authority of the Fabian canon in its original form (without the word depositus) ${ }^{38}$ and another Carolingian confection ascribed to >Pope Stephen<, which said much the same thing, ${ }^{39}$ quoted verbatim. The Luccesi canons were excommunicated and deprived of office and benefice ${ }^{40}$; the Life of St Anselm of Lucca claimed that Countess Matilda of Tuscany, "calling them slaves, summoned them to the service of the curia. $\aleph^{41}$ The judgment had no effect, but its interpretation of the Fabian canon is important in the present context.

Gratian was not unaware of the non-judicial meaning of curia, having presented a string of genuine canons from early popes (Innocent I 401-417, Gelasius I 492-496, Gregory I 590604) which stated that men assigned to public administrative service (curiales) were debarred from sacred orders, ${ }^{42}$ but he did not recognize that the curia in the >Pius and >Fabian canons described a similar administrative institution. Reading it to mean (secular) court, he confidently declared at the end of his summary, following Questio 1, chapter 30, that:

In a criminal case no cleric is to be produced before a civil judge, except with the consent of his bishop, as, for example, when they (sic) are found incorrigible, and then, having been deprived of office, they are handed over to the curia, as Pope Fabian affirms, ${ }^{43}$

followed by the Fabian canon (c.31).

37 What are we to make of the incident in which Ivo of Chartres rebuked the bishop of Orléans who had caused a deacon whom he had freed at Ivo's request to be taken to prison by his servants, and verberatum, spoliatum, per manus servorum trahi fecistis ad carcerem, et curiae traditum...non damnatus a vobis curiae traderetur, ubi more furis, contumeliis et injuriis quotidianis cruciaretur? PL, clxii, 64-65 no. 53 at 64.

38 The term >deposed (depositus) < was not in the >Pius canon « as it appeared in Pseudo-Isidore, but it had been intruded, intentionally or by mistake, into two of Gratian's sources: Anselm of Lucca, Collectio canonum (c.1083), viii.17 (PL, cxlix, 519) and the Polycarpus by Cardinal Gregory of S. Crisogono (1111), iv.35.22: www.mgh.de/datenbanken/kanonessammlung-polycarp/ (retrieved on 17 November 2017).

39 Pseudo-Isidore, ed. Hinschius, 186, c.11; Gratian, C.3 q.4 c.8: Clericus vero qui episcopum suum accusauerit, aut ei insidiator extiterit, non est recipiendus, quia infamis effectus est, et a gradu debet recedere, ac curiae tradi serviturus.

40 Gregory VII, $P L$, cxlviii, 546-547 (Reg. VII.2).

41 PL, cxlviii, 910, Prolatis ergo canonibus, et lecto capitulo sancti martyris et episcopi Fabiani, qui conspiratores et insidiatores suorum episcoporum curiae tradendos instituit, judicio totius sanctae synodi etiam ipsi curiae traduntur. Tunc fidelis et prudens marchionissa Mathilda servos illos appellans, in servitutem curiae vocavit eos.

42 Gratian, D. 34 c.10; D.50 c.59; D. 51 cc. 1-3, 5; D. 53 c.1; D. 55 c.1. Cf. D.61 dictum ante c.11, etc.

43 Gratian, C.11, dictum post q.1 c.30. 
The third case, the so-called 'Gregorian< canon, attributed in Gratian's Decretum to Pope Gregory I (590-604), was a genuine letter of the sixth-century Pope Pelagius I (555/1-560/1) addressed to the Byzantine general Narses, then controlling northern Italy in the aftermath of the Gothic wars launched by Emperor Justinian. The key passage read, ${ }^{44}$

We request that you send the pseudo-bishop Paul of Aquileia and the bishop of Milan to the most merciful prince under appropriate guard, so that [...] [each] may be subject to the punishment of the canons.

This also related to a form of 'handing over «, but it was not for secular judgment or secular punishment. The two bishops were to be transferred to Constantinople where the emperor (Justinian) would impose the appropriate canonical penalty on them..$^{45}$ Since both the identity of the pope and the context were unknown to Gratian, he could be forgiven for interpreting it to mean, as he proclaimed in the heading, that "Those whom the Church cannot correct may be corrected by princes, $\aleph^{46}$ although the phrase "according to the canons « might have given him pause.

The fourth example derives from a novella of Emperor Justinian. ${ }^{47}$ As transmitted by Gratian, its key clause reads: ${ }^{48}$

If a case concerning a criminal matter arises, competent [judges] may, when required, impose a judgment consonant with the laws, but in such a way that the discussion of the case should not exceed two months from its formal presentation [...]

Even so, "A cleric may not be punished unless having been found guilty he is deprived of the priesthood or clerical honour by his bishop.« This imperial decree subjected clerics accused of secular crime to secular process, but the cleric could not be punished - that is, subjected to the penalties of the public law - unless he was deprived of his clerical status after his guilt had been proved and the praeses had determined that it merited the punishment of the leges. Until then, his person was sacrosanct. After supporting this imperial constitution with canons from the early Church councils of Chalcedon (451) and Agde (506), ${ }^{49}$ Gratian summed up his argument in his long comment following c.47: $:^{\circ}$

44 Gratian, C.11 q.1 c.20: Istud est, quod a uobis poposcimus [...] ut Paulinum Aquileiensem pseudoepiscopum, et illum Mediolanensem episcopum ad clementissimum principem sub digna custodia dirigatis, ut et iste [...] canonum uindictae subiaceat.

45 Paul was suspected of Arianism, having opposed Justinian's condemnation of the Three Chapters (544) and the bishop of Milan had consecrated him against papal instructions. Narses took no action since he did not wish to inflame an already disturbed situation in the region.

46 Gratian, C.11 q.1 c.20, rubric.

47 Novellae, 83pr§2 = Authenticum, ed. Haenel, 84pr§2.

48 Gratian, C.11 q.1 c.45; cf. Ivo, Decretum, vi.427 (Constitutio 83); Anselmo dedicata, 3.243 (250).

49 Gratian, C.11 q.1 cc.46-47. The Agde canon also occurs in Gratian, D.50 c.7: Si episcopus, presbiter, aut diaconus capitale crimen commiserit, aut cartam falsauerit, aut falsum testimonium dixerit, ab offitii honore depositus in monasterio detrudatur et ibi quamdiu uixerit laicam tantummodo communionem accipiat.

50 Gratian, C.11 q.1 dictum post c.47: Ex his omnibus datur intelligi, quod clericus ad publica iudicia nec in ciuili, nec in criminali causa est producendus, nisi forte ciuilem causam episcopus decidere noluerit, uel in criminali sui honoris cingulo eum nudauerit. [...] Prohibentur ergo clerici a cognitione negotiorum secularium uirorum, non secularium causarum. Negotia quippe clericorum, siue criminalia siue ciuilia fuerint, non nisi apud ecclesiasticum iudicem uentilanda sunt. 
From all these it can be deduced (intelligi) that, neither in a civil nor in a criminal case is a cleric to be brought before public courts unless the bishop does not wish to hear the civil case, or in a criminal case, has stripped him of his status. [...] Therefore clerics are forbidden cognizance of the cases of secular men but not of secular cases. For clerical cases whether criminal or civil can be brought forward only before an ecclesiastical judge.

With all its ambiguities, Gratian's analysis became the essential starting-point for the definition of clerical exemption thereafter. In one of the earliest commentaries on the Decretum, finished $c .1164,{ }^{51}$ the Bolognese jurist Rufinus summarized what he saw as the essence of the Master's teaching: ${ }^{52}$

Bishops and priests cannot for any case be accused before a secular judge, because secular judges cannot judge them [...]. What therefore is to be done? Let the cleric or bishop be summoned before the ecclesiastical judge, and after he has been convicted of a secular crime by lawful proof, if the crime is particularly terrible, let him be stripped of the dignity of his office and then released to be punished by the secular judge according to the criminal laws (a seculari iudice secundum leges publicas puniendus).

To Gratian's test of sincorrigibility<, Rufinus added the test of grievous criminality as grounds for exposing clerics to secular punishment, and he very much clarified the language. The ambiguous curia is dropped in favour of ssecular and recclesiastical judges.

Outside the classroom, bishops began to raise questions about the application of the privilegium fori to concrete problems in their own dioceses, to which popes replied on an ad hoc basis. Their responses show the papal Curia struggling to maintain the principle of clerical immunity while allowing that the protection could be withdrawn or withheld in certain situations. This adaptation can be traced through the pontificates of five popes (Eugenius III, Lucius III, Urban III, Celestine III, and Innocent III), whose responsa helped to form the new >decretal law on clerical privilege in the Liber Extra, also known as the Gregorian Decretals. This compilation of what contemporaries called snew law`, supplementary to Gratian, was issued by Pope Gregory IX in 1234 for use in schools and courts throughout the Latin Church.

The first modifications came from Pope Eugenius III (1145-1153) in a decretal letter known from its opening Latin words as Litteras fraternitatis, issued from Viterbo on 26 November 1146 in reply to questions posed by Bishop Jocelin of Salisbury..$^{53}$ Asked if Jocelin should protect delinquent clergy from arrest by secular authorities, Eugenius said that he should not, and defined rapostasy< as grounds for withdrawing clerical immunity: ${ }^{54}$

51 Argued by Gouron against Singer: Sur les sources civilistes, at 68 .

52 Rufinus, Summa decretorum, ed. Singer, 309: Quid igitur faciendum erit?... Conveniatur clericus vel episcopus ante iudicem ecclesiasticum, et postquam ibi fuerit de crimine forensi legittima probatione convictus, si adeo horrendum crimen fuerit, spoliabitur proprie dignitatis officio et dimittetur post hec, a seculari iudice secundum leges publicas puniendus.

53 Jocelin de Bohun, bishop of Salisbury 1142-1184: JohnS, Letters, ii, 360-361 n. 1.

54 Litteras fraternitatis tue: JL 8959; WH 736§b: Liber Extra, ed. Friedberg, 5.9.1 (wrongly attributed to Alexander III): Praeterea clerici, qui, relicto ordine clericali et habitu suo, in apostasia tanquam laici conversantur, si in criminibus comprehensi teneantur, per censuram ecclesiasticam non praecipimus liberari. For the original letter, with variants, arenga and date, see Epistolae pontificum Romanorum ineditae, ed. Loewenfeld, 103-104 no. 199. For this concept of rapostasy<, see Gratian, D.50 c.69: Hii qui post sanctam religionis professionem apostant et ad seculum redeunt (cf. Arles (443/452). 
We do not command that clerics who, having abandoned their order, habit, and office, live in apostasy like laymen, should be freed by ecclesiastical censure if they are held after being seized in the commission of crimes.

The scensure to which Eugenius referred was canon 15 of the Second Lateran Council (1139), a canon known by its opening words as Si quis suadente, which had imposed automatic excommunication on all who laid violent hands on clerics or monks, a sentence which could not be lifted by the diocesan bishop, except at the point of death, until the delinquent had gone in person to the Apostolic See. ${ }^{55}$ Eugenius implied that lapsed clerics who committed crimes were not protected by Si quis suadente, on the unspoken principle that "he who abuses a privilege deserves to lose it. ${ }^{56}$ Similarly, Eugenius instructed Bishop Jocelin to forbid his clerks to act as estate managers for laypersons: if they did, and were seized for fraud in a financial matter, it was improper that they should be protected by the Church in which they had created scandal. ${ }^{57}$ In other words, they should not be allowed to appeal to $S i$ quis suadente if they were suspected of misappropriation.

These replies should be seen in the context of the civil war in England (1138/1139-54) between King Stephen and the `Empress Matilda, which was causing localized breakdowns in law and order. Jocelin of Salisbury had sought special authority to deal with clerical criminals (malefactores) in his diocese, and the full text of the pope's response, which was not transmitted in the canonical tradition, makes it clear that Eugenius was authorizing exceptional action for exceptional cases.

55 Lateran II, ed. Alberigo, c.15: Item placuit ut si quis, suadente diabolo, huius sacrilegii reatum incurrerit quod in clericum vel monachum violentas manus iniecerit, anathemati subiaceat, et nullus episcoporum illum presumat absolvere, nisi mortis urgente periculo, donec apostolico conspectui presentetur, et eius mandatum suscipiat: Brett and Somerville, Transmission of the Councils, at 267. The same decree, without the spoint of death exception, had been issued at Clermont in 1130 and Reims in 1131 (ibid., 253). When the Lateran canon reached Gratian (C.17 q.4 c.29) it was given an apparatus of Roman authorities in dictum post c. 29, which cited the Codex and Digest by title and lex: primo libro Codicis legitur, titulo >de episcopis et clericis [Codex Iustinianus, ed. Krueger, 1.3] et lege: sSi quis in hoc genus sacrilegii proruperit [Codex Iustinianus, ed. Krueger, 1.3.10pr] et in Digestis titulo 'Ad legem Iuliam pecuniarum repetundarum< [recte: Ad legem iuliam peculatus et de sacrilegis et de residuis: Dig. 48.13; cf. Justinian's Institutes, trans. Birks and McLeod, 4.18.9], lege ultima [recte: prima: Dig. 48.13.1] which declared that all violence within or against churches, cults, priests and ministers should be treated like public crime and treason and punished capitali sententia.

56 Cf. Simplicius (468-483), PL, lviii, 35-37 ep. 2, at 36: nam privilegium meretur amittere qui permissa sibi abutitur potestate; Ivo of Chartres, Decretum, 5.140 (qu. Simplicius), PL, clxi, 371: Nam privilegium meretur amittere, qui permissa sibi abutitur potestate; Hugh of St.Victor, Expositio Moralis in Abdiam, PL, clxxv, 373: quia privilegium meretur amittere, qui concesso dono abutitur, vel permissa potestate; Wibald of Stavelot, PL, clxxxix, 1204-1210 no. 114, at 1208: privilegium meretur amittere qui privilegii abutitur libertate; Innocent III, below, at n. 101.

57 Liber Extra, ed. Friedberg, 3.50.1 (wrongly addressed to the bishop of Lucca): Sacerdotibus autem et clericis tuis denuncies publice, ne ministri laicorum fiant, nec in rebus eorum procuratores exsistant. Quod si postmodum facere praesumpserint, et occasione ipsius administrationis propter pecuniariam causam deprehendantur in fraude, indignum est eis ab ecclesia subveniri, per quos constat in ecclesia scandalum generari. It is significant that Henry II took legal action against Thomas Becket in 1164 for alleged peculation: see Duggan, Roman, Canon, and Common Law, 379408 , at 386-387. 
Therefore, desiring to have regard for the peace and tranquillity [of your diocese], we order you to restrain your criminals with appropriate punishment, and we are prepared to subject them to more severe penalty if they do not come to their senses and desist from their depravity ${ }^{58}$

What that ımore severe penalty` may have been is uncertain, but it may have implied a willingness to abandon such violent men to the tender mercies of the secular power if they remained recalcitrant. It is unlikely, however, that he contemplated a general withdrawal of the privilegium fori. Indeed, earlier in the same year (9 June 1146), in a letter to Bishop Tebaldo of Verona (1135-1157), Eugenius had condemned the exercise of disciplinary power over delinquent clerics by laymen. After stating the principle that sclerical affairs and the discipline of clerks belong to bishops and their officials`, the pope condemned the practice of laymen sseizing and correcting (distringere et corrigere) clerics who committed sexual sins (si carnaliter peccaverint) and mandated the bishop to restrain them by ecclesiastical censure. ${ }^{59}$ Although this letter survives only in a single copy made in Verona, the key segments of the more ambiguous Salisbury consultation were copied into collections of decretal letters in England and then transmitted to Continental collectors, eventually becoming part of the formal law studied in Bologna,${ }^{60}$ and so helped to consolidate Gratian's reading of the earlier tradition.

Meanwhile, the question of privilegium fori blew up in a big way in England eighteen years later (1164), when King Henry II decreed in clause 3 of a set of royal edicts known from where they were issued as the >Constitutions of Clarendon that: $^{61}$

Clerks charged and accused of any matter shall ... come before the king's court to answer there concerning matters which shall seem to the king's court to be answerable there, and before the ecclesiastical court for what seems to be answerable there, but in such a way that the king's justice shall send to the court of holy Church to see on what ground (qua ratione) the case is there tried. And if the clerk shall be convicted or shall confess, the Church ought no longer to protect him.

How far Henry's formulation was compatible with the canon law is a moot point: note its broad reach - "accused of any matter...concerning any matters which shall seem to the king's court to be answerable there - and the total absence of episcopal discretion. Equally

58 Ideoque paci et tranquillitati eius [Salisbury diocese] intendere cupientes, malefactores tuos animadversione debita coerceri precipimus eosque severiori vindictae, nisi resipiscant et a sua pravitate desistant, pro debito officcii nostri subiicere parati erimus: Epistolae pontificum Romanorum ineditae, ed. Loewenfeld, 103.

59 Clericorum negotia et correctiones ad episcopos vel ad eorum ministros specialiter pertinere nullui credimus esse incognitum, in Arabello, ‘Nulli credimus esse incognitum‘, 233-244, at 244, from Verona, Bibl. Capitolare, cod. CV (98), fol. 2va-b, Clericorum negotia, Tavola 1: copied directly from the original responsum in script which reproduced Chancery style, with capitals and titles and the date: DAT. VIT[ER]BI.V.IDUS IUN[II].

601 Comp. 3.6.2 (§a), 5.8.2 (§b: >Alex. III $)$ ), 3.37.8 (§c: addressed `Lucell. Archiep.`); Liber Extra, ed. Friedberg, 3.6.2 (§a), 5.9.1 (§b: ^Alexander III ), 3.50.2 (§c: ২Lucanensi episcopo «).

61 Translated from Stubbs, Select Charters, 164-165. 
moot is its accuracy as a statement of English customary law, ${ }^{62}$ but the matter was settled, broadly in the Church's favour in 1175/1176, when Henry II reached a compromise following negotiation with Pope Alexander III's legate, Hugh Pierleone:

We have conceded ... that a clerk shall not in future be drawn in his own person before a secular judge for any criminal matter (de aliquo criminali), or for any trespass (de aliquo forifacto), except the trespass of my forest, and except for lay fee for which lay service is owed to me or to another secular lord.

Breach of the forest law was a significant exception, ${ }^{63}$ since its penalties could be brutal,,${ }^{64}$ but the main principle of clerical exemption from secular punishment held for criminal cases throughout the Middle Ages in England, with some significant modifications, and was not finally abolished until 1827 . Generally speaking, a cleric who pleaded clergy was tried, and then released to the bishop's proctor, with notification of the verdict for the bishop's information. If he had been acquitted, there was nothing further to do; if he had been convicted, he could try to purge himself in the bishop's court; if he failed, he would be imprisoned for life in an ecclesiastical prison. ${ }^{65}$ The question of ordeal did not arise, since that form of proof was abolished in England in 1219 in the wake of the Fourth Lateran Council's withdrawal of ecclesiastical involvement in the process in $1215 .{ }^{66}$ The number of clerics involved seems to have been small and mostly confined to the category of clerks who had received the tonsure as a mark of their clerical status but had not been promoted to even the lowest clerical order, ${ }^{67}$ and the majority were found not guilty. Generally speaking, the process worked well so well, in fact, that from the later Middle Ages onwards, as Dick Helmholz showed, in England, clerical privilege was »enlarged to encompass all laymen who could pass a sliteracy test‘

62 It is worth remembering that while he was bishop of Hereford (1148-1163) Gilbert Foliot expressed astonishment that Elias de Say had tried a priest in his own court: sa power which kings and emperors, in spite of much sweat and labour, have not been able to obtain against her until this day؛: van Caenegem, English Lawsuits, ii, no. 413.

63 The Forest justices, protected against Si quis suadente by the king, were given explicit authority to proceed against clerics in the Assize of the Forest (1184), c.9, Stubbs, Charters, 188: "[the king] has given strict orders to his foresters that if they find any such [clerics] trespassing there, they shall not hesitate to lay hands upon them in order to arrest them and to secure their persons, and he himself will give them his full warrant (praecepit bene forestariis suis quod si invenerint eos forisfacientes, non dubitent in eos manum ponere, ad eos retinendum et attachiandum, et ipse eos bene warantizabit)."

64 For the Forest Law, which preserved large tracts of land for royal hunting, see Green's article in this special issue. In 1159 the prominent English cleric John of Salisbury railed against the brutality of the foresters who "subject God's image to rexquisiter tortures in defence of wild animals and have not feared for a brute beast's sake to destroy a human being (homo) whom the Son of God redeemed with his blood«: Policraticus, i.4 (PL, cxc, 396). Stubbs (Charters, 185) described it as "cruel to man and beast.«. The worst penalties (death and mutilation) were abolished in the Charter of the Forest (1217): Stubbs, Charters, 346-347, Nullus de cetero amittat vitam vel membra pro venatione nostra. Instead, if he had the wherewithal to pay, the guilty man was to be heavily fined; if he did not, he was to be imprisoned for a year and a day, after which he would be freed if he could find pledges to guarantee his future good behaviour; if he could not find pledges, he had to abjure the realm.

65 London Trailbaston Trials, ed. Pugh, 14-16; Wiltshire Gaol Delivery, ed. Pugh, 14-16; cf. Pugh, Imprisonment in Medieval England, 134-139. See Helmholz, Oxford History of the Laws, 508-514.

66 Lateran IV, ed. Alberigo, c.18, Sententiam sanguinis, specifying the ordeals of cold water and hot iron; Councils and Synods, ed. Whitelock, 2/i, 49.

67 Wiltshire Gaol Delivery, ed. Pugh, 252, s.v. clergy, benefit of, pleaded; delivered to the bishop. 
and eventually extended to women as well.« In this way, »benefit of clergy became a means of protecting a segment of the population from the harsh punishments customarily meted out to criminals under the common law. It also made important differences in the internal life of English criminal law. Determining which crimes were sclergyable and which were not became a means of drawing distinctions between different kinds of criminal offenses and eventually of developing the substantive law itself. ${ }^{68}$

Outside England, Pope Alexander III maintained the principle of clerical jurisdictional immunity in responses to Uppsala and Salerno. In the first, to Archbishop Stephen in 1171/1172, which cited Gratian liberally, ${ }^{69}$ Alexander declared that »clerics should not undergo secular trials, especially the ordeal of hot iron (igniti ferri examen) or any other satrocious trialk (exsecrabile judicium $\ll ;^{70}$ in the second, a much better known response to Bishop Romuald II of Salerno in 1177 (Licet preter), he re-stated the principle that clerics were subject only to episcopal jurisdiction: ${ }^{71}$

At si clerici: If clerics are convicted or confess before a secular judge, they are not to be condemned by their bishop because a sentence issued by someone who is not his own judge is not binding;

Si vero coram episcopo: but if they confess or are convicted of crimes by lawful proof before their own bishop they should be suspended from their orders and permanently removed from service at the altar.

De adulteriis: but for adultery and other lesser crimes, their bishops may allow them to serve in their orders after they have done penance.

before concluding that a cleric deposed for his excesses in office "should not be handed over to the secular judge or crushed with a double penalty. ${ }^{72}$ This was an oblique reference to the >double punishment argument deployed during the Becket controversy. Two years later in the Third Lateran Council (1179), Alexander imposed excommunication on any layman who compelled clerics or bishops to submit to his judgment. ${ }^{73}$

Although Pope Lucius III (1181-1185) maintained the principle when he instructed the archbishop of Esztergom that clerics could be judged only by ecclesiastical judges, even if local custom held to the contrary in respect of thieves, ${ }^{74}$ he recognized that there were circumstances in which it was necessary for the Church to rely on secular force in its own defence. The catalyst was the forgery of papal letters that was reported to Lucius in 1185 .

68 Helmholz, Ius Commune in England, 190.

69 Gratian, C.11 q.1 cc.5, 12, 14, 20, and 22.

70 Constituti a Domino, Tusculum, 10 September, 1171/2: PL, cc, 854-860 no. 979 (JL 12117), at 858. For date, see Falkenstein, Die Sirmondsche Sammlung, esp. 277 no. 19: JL 12117.

71 WH 620§f: Liber Extra, ed. Friedberg, 2.1.4. See Landau, Ursprünge und Entwicklung.

72 Liber Extra, ed. Friedberg, 2.1.4, in fine: sed non debet quemlibet depositum pro suis excessibus, quum suo sit functus officio, nec duplici debeat ipsum contritione conterere, iudici tradere saeculari.

73 Lateran III, in Conciliorum oecumenicorum decreta, ed. Alberigo, c.14§d: sane quia laici quidam ecclesiasticas personas et ipsos etiam episcopos iudicio suo stare compellunt, eos qui de cetero id praesumpserint, a communione fidelium decernimus segregandos.

74 >Clerici vero', Liber Extra, ed. Friedberg, 2.1.8, §d of In apostolice sedis, WH 14, datable only by Lucius III's pontificate. For the full text, see Duggan, Decretal Letters to Hungary, at 14-17, esp. 16; repr. with the same pagination in idem, Decretals and the Creation of the >New Lawr, no. V. 
This was no new problem. As early as 1131, the deathbed confession of the French monk, Guerno of St-Médard (Soissons), was recounted to Pope Innocent II at a council at Reims (1131). Guerno had confessed to forging papal privileges for monastic houses in England and Normandy, ${ }^{75}$ among which were St Augustine's and Christ Church, Canterbury and St-Ouen (Rouen). ${ }^{76}$ Fifteen years later (1146), Pope Eugenius III had instructed Bishop Nicholas of Cambrai to deprive of office and benefice the canons or clerics who had presented a forged papal letter, until they brought the document to his presence to answer to him for the offence. ${ }^{77}$ Twenty or so years later still (1160-1174), Pope Alexander III instructed Bishop William de Turba of Norwich to deprive the priest who had forged (falsavit) the papal letters which the bishop had sent to the Curia and, "if he can be found «, place him in "some monastery of strict religion" (aliquod monasterium districte religionis) to suffer the penalty for so grave a crime, so that others may be deterred. If any others are found, the bishop can hold them in the strictest custody (artissime custodie), without right of appeal, "until you receive an apostolic mandate on the matter.$^{78}$

At a time when ecclesiastical rights and privileges as well as much of the practice and jurisprudence of the Latin Church were being shaped by reliance on papal privileges and judicial letters (decretales), the forgery or falsification of papal documents presented a major problem, and popes from Lucius III (1181-1185) onwards were forced to authorise increasingly strong actions to punish and deter. Responding to a report from Archbishop Walter of Rouen that persons had been discovered forging litteras apostolicas in the lands of the English king (Henry II), Lucius authorized the archbishop in Improba pestis falsitatis (a letter issued from Verona, 16 October 1185), to deprive the guilty clerics of their order and benefice and to keep them in close custody until the pope issued further instructions, while any laymen should be handed over to the king for judgment, "so that this pestilence which is recognized as pernicious by everyone may be condemned by both ecclesiastical and secular judgment, together with its authors ".$^{79}$ The two powers were to collaborate in the eradication of the scourge of forgery, which affected both jurisdictions. Although important as evidence of curial attitude to forgery, this letter had little long-term impact, since it was not included in the Liber Extra.

75 Guerno's confession was recorded in a letter to Adrian IV from Archbishop Hugh of Rouen, who heard it from Bishop G. of Chalons, formerly abbot of St-Médard, who heard the monk's confession: Literae Cantuarienses, iii, ed. Brigstocke Sheppard, 365-367; cf. Berkhofer, Guerno the Forger; idem, Forgery and Alexander III's Scripta autentica. For the broader problem, see Duggan, Improba pestis falsitatis.

76 Morey and Brooke, Gilbert Foliot, 131 and n. 2; cf. John of Salisbury, Letters, i, ed./trans. Millor et al., nos. 57, at 98 (where the forging of papal letters is called lèse majeste), 67, 73 at 117, and 86.

77 PU Niederlanden, i, 175 no. 59: tibi precipimus, quatenus canonicos siue clericos, qui falsum scriptum tibi ex parte nostra presentauerunt uel presentari fecerunt, officio uel beneficio priues ecclesiastico, donec cum eodem scripto responsuri et satisfacturi nostro se conspectui representent.

78 Last § of Ex tenore litterarum: WH 488§d; Collectio Belverensis, 14; Appendix concilii Lateranensis, ed. Crabbe, 26.3; 1 Comp. 5.16.3; cf. Claustr. $132 \S 4$. The Collectio Belverensis, the Appendix concilii Lateranensis, and 1 Comp. read si inveniri poterit; Claustr. reads si inde evinci poterit.

79 ut iudicio videlicet tam ecclesiastico quam mundano pestis illa que communiter omnibus pernitiosa dinoscitur cum suis actoribus condempnetur: WH 546; 2 Comp. 5.9.1 (whence Mansi, 22, 482) mistakenly reads litteras publicas for litteras apostolicas. The correct reading is transmitted in 1 Rot. 17.9. For the correct text, see Duggan, Improba pestis falsitatis, 354-355, no. 17 . 
It was another shocking case of forgery, discovered by the same archbishop of Rouen, which precipitated the fateful step of exposing clerical criminals to a form of punishment similar to that imposed on laymen, although in this instance, it was a prelate who imposed it. When Archbishop Walter asked what should be done with clerics who had forged the seal of King Philip II of France, Pope Urban III (1185-1187) replied in the decretal Ad audientiam that they should not lose a membrum (which could mean castration), nor should he inflict a corporal penalty that might endanger life. Instead, after degrading them, he should have them branded as forgers and compelled to abjure the province. ${ }^{80}$ It is highly likely that Walter had reported the severe penalties, then current practice in the Anglo-Norman realm, where not only counterfeiters of coin but also those found with false money in their possession risked castration and the loss of their right hands. ${ }^{81}$ Urban III's solution - degradation, branding, and expulsion from the province (Normandy) - seems to me to be an echo of the Roman Lex Cornelia de falsis, which prescribed death for slaves and deportation for everyone else. ${ }^{82}$ But the pope stopped short of transferring the guilty clerics to the secular jurisdiction for punishment.

That step was taken, with considerable reluctance, by Pope Celestine III in Cum non ab homine, which instructed Archbishop Eirik of Nidaros in 1191-1192 that neither kings nor any secular person could judge clerics rapprehended for robbery, homicide, perjury, or any other crimes،. Instead they should be arraigned, tried, and deposed by their bishops, and if they remained defiant and incorrigible after excommunication and anathema, since the Church had nothing further that it could do, they could be restrained by the secular power »by exile or any other lawful penalty « ${ }^{83}-$ a phrase which excluded mutilation or death. The test for Celestine, as it had been for Gratian and his principal commentators, including Rufinus, ${ }^{84}$ was incorrigibility, since the Church has nothing further (cum ecclesia non habeat ultra).$^{85}$

Pope Innocent III took the next steps, first in response to the problem of industrial-scale clerical forgery ${ }^{86}$ and then to the question of violent clergy. In the opening months of his pontificate in 1198, Innocent reported the discovery, in Rome itself, of a group who had forged Celestine III's seal, as well as his own, to validate counterfeit papal letters, together with numerous letters already sealed. The culprits were imprisoned on Innocent's orders and, in letters to Archbishop William of Reims and all archbishops, the pope warned the whole Latin Church about the risk of counterfeit papal letters reaching their provinces. The recipients

80 Ad audientiam: 1 Rot. 17.16; Gilbertus Anglicus (1203) 5.7.2; X 5.20.3.

81 Green, Government of England, 89-90.

82 Dig. 48.10. The crimen covered every kind of forgery or falsification, including the use of false documents or seals sfraudulently and with evil intent (dolo malo)<. Urban III, the former Umberto Crivelli, had been a professor of law at Bologna in the 1150 s.

83 Cf. Urban III, supra, at nn. 79 and 81

84 Supra, at n. 51.

85 JL 17639 (to the archbishop of Nidaros): WH 273; Gilb. 2.1.1; Liber Extra, ed. Friedberg, 2.1.10§§ad: sive in furto vel homicidio vel periurio aut falso testimonio seu quibuscumque fuerint criminibus deprehensi. For the text, lacking the arenga, see Holtzmann, Krone und Kirche, 397-400 no. 13. For the arenga, `Cum non ab homine ... conuocauerit‘, see idem, "Collectio Seguntina«, 431 no. 43, which also provides the date. Full text and translation in Duggan, Manu sollicitudinis, 231-235 no. 3.

86 For the general problem, see Herde, Römisches und kanonistisches Recht. 
were ordered to issue a general sentence of excommunication (which could be raised only by special papal mandate) against any who did not within twenty days hand over or destroy false letters in their possession, lest the survival of such forgeries caused injury to anyone in the future ${ }^{87}$ This particular nest of forgers may have been active for some time. Six years earlier (December 1191), Pope Celestine III had alerted the dean of Rouen and the Norman bishops about letters forged in Rome (in Urbe) and advised them to seize any suspicious letters which might have reached them. ${ }^{88}$

But Innocent did not stop there. As well as initiating reforms in the papal Curia to reduce the opportunity for such criminal activity in the future, ${ }^{89}$ he issued a general constitution in 1201, known as Ad falsariorum confundendam malitiam. This anathematized all forgers of papal letters, together with their aiders and abettors, and decreed that clerics apprehended for forgery should be degraded by the ecclesiastical judge and handed over to the secular power for punishment according to the legal constitutions (legitimas constitutiones) by which laymen convicted of forgery were lawfully punished. This marked the first significant breach in the concept of clerical immunity from secular punishment, ${ }^{90}$ but it was sufficiently contentious for Bishop Peter of Paris ${ }^{91}$ to ask for clarification in 1209 in relation to a forger seized in Paris on papal orders. The clarification came in the decretal Novimus expedire, in which Innocent, citing his own decree (Ad falsariorum), and the opinion of "some of his predecessors " (almost certainly Celestine III in his Cum non ab homine), ${ }^{92}$ explained the process of traditio curie: ${ }^{93}$

87 Dura saepe, Liber Extra, ed. Friedberg, 5.20.4 (PL, ccxiv, 202-203 no. i.235), 21 May 1198: bullas tam sub nomine nostro, quam bonae memoriae Coelestini Papae praedecessoris nostri, quas falso confinxerant, et quam plures literas bullis signatas invenerimus apud eos.

88 Per falsarios, 21 December 1191: Duggan, Improba pestis falsitatis, 356-357 no. 19: faciatis eos omnes omni dilatione postposita capi et tamdiu sub arcta custodia detineri, donec id nobis intimatum, ut quid exinde fieri debeat vobis significare possimus.

89 Zutshi, Innocent III, at 86-87 (cf. Liber Extra, ed. Friedberg, 5.20.4). The consequences of this reform of chancery practice are manifest from 1204 in the way in which documents were marked with the initials of the scribe and of the notary who oversaw their issue, as well as notations which marked those to be copied into the papal register: ibid., 9294. For the reorganization of the registry in 1206 under the new chancellor, John, cardinal deacon of S. Maria in Cosmedin, see Selected Letters of Pope Innocent III concerning England, ed. Cheney and Semple, xxix.

90 Liber Extra, ed. Friedberg, 5.20.7: saeculari potestati tradantur secundum constitutiones legitimas puniendi, per quam et laici, qui fuerint de falsitate convicti, legitime puniantur.

91 Peter de la Chapelle, bishop of Paris 1208-1219.

92 Above, at n. 84.

93 Liber Extra, ed. Friedberg, 5.40.27 (16 February, 1209): ut clericus, qui propter hoc vel aliud flagitium grave, non solum damnabile, sed damnosum, fuerit degradatus, tanquam exutus privilegio clericali saeculari foro per consequentiam applicetur, quum ab ecclesiastico foro fuerit proiectus; eius est degradatio celebranda saeculari potestate praesente, ac pronunciandum est eidem, quum fuerit celebrata, ut in suum forum recipiat degradatum, et sic intelligitur tradi curiae saeculari; pro quo tamen debet ecclesia efficaciter intercedere, ut citra mortis periculum circa eum sententia moderetur. Cf. $P L$, ccxv, 1562-1563 no. xi.257. It was this definition that led Maitland to argue that Henry II's proposals for traditio curie in Clarendon's cl. 3 was in conformity with canon law: Maitland, Roman Canon Law, 144-145. 
A cleric who has been degraded for this (forgery) or any other grave crime (grave flagitium), not merely worthy of condemnation (damnabile) but pernicious (damnosum), is then brought to the secular court (forum) as one stripped of his clerical privilege, when he is cast out of the ecclesiastical forum; his degradation must be conducted in the presence of the secular power, which must be notified in advance so that it can take the degraded cleric into its forum, and he is thus understood to be surrendered to the secular court. Nevertheless, the Church should intercede effectively (efficaciter) on his behalf so that the sentence does not involve the danger of death (periculum mortis).

In this particular case, Innocent directed that the cleric was to be confined in prison for life, but he extended the application of traditio curie to other grave and pernicious crimes. Here he was almost certainly following the example of Lucius III's constitution, Ad abolendam, issued at Verona in 1184, which decreed that degraded and excommunicated heretic clerks should be handed over to the secular authorities to receive due punishment (animadversione debita), unless they immediately repudiated their heresy and did penance. ${ }^{94}$ The same phrase was repeated in Innocent III's Lateran IV, c. $3^{95}$ and in Pope Gregory IX's Excommunicamus of 1231: "Those condemned by the Church should be abandoned to secular judgment to be punished with due severity, clerics being first degraded from their orders. $\aleph^{96}$

Innocent III did not define the meaning of "not merely worthy of condemnation but pernicious «, but he probably had in mind the serious crimes enumerated in Pope Celestine III's Cum non ab homine, which had listed robbery, homicide, perjury, and false testimony and specified "exile or some other lawful penalty", as well as Pope Urban III's exclusion of mutilation or any corporal punishment that might endanger life. ${ }^{97}$ Both letters had already entered the legal curriculum in Bologna, having been included in a Bolognese collection made by the English canonist Gilbertus Anglicus in $1203 .{ }^{98}$ Included in the Liber extra promulgated in 1234, Innocent III's Novimus expedire opened the door to more routine rendition of degraded clerical criminals in cases deemed exceptionally grave and pernicious by the ecclesiastical court. It became the ultimate penalty in the Church's armoury. In all cases, however, the right to judge clerical criminals remained with ecclesiastical judges.

94 Liber Extra, ed. Friedberg, 5.7.9: clericus est vel cuiuslibet religionis obumbratione fucatus, totius ecclesiastici ordinis praerogativa nudetur, et sic omni pariter officio et beneficio spoliatus ecclesiastico, saecularis relinquatur arbitrio potestatis, animadversione debita puniendus, nisi continuo post deprehensionem erroris ad fidei catholicae unitatem sponte recurrere, et errorem suum ad arbitrium episcopi regionis publice consenserit abiurare, et satisfactionem congruam exhibere.

95 Lateran IV, in Conciliorum oecumenicorum decreta, ed. Alberigo, c.3 (X 5.7.13): Damnati vero praesentibus saecularibus potestatibus aut eorum ballivis relinquantur animadversione debita puniendi, clericis prius a suis ordinibus degradatis, ita, quod bona huiusmodi damnatorum, si laici fuerint, confiscentur: si vero clerici, applicentur ecclesiis, a quibus stipendia receperunt. It was not in his decree against heretics, Vergentis in senio (1199), X 5.7.10-11.

96 Liber Extra, ed. Friedberg, 5.7.15: Damnati vero per ecclesiam saeculari iudicio relinquantur, animadversione debita puniendi, clericis prius a suis ordinibus degradatis.

97 Above at nn. 82 and 79.

98 Gilbertus Anglicus (1203), 5.7.2 (Urban III); 2.1.1 (Celestine III). `Gilbertus und Alanus«. Designed as a supplement to 1 Comp. 
The need to provide secure detention for aggressive clerics also provided further grounds for relaxing the reach of Si quis suadente. In 1203 Innocent III replied to a consultation from Archbishop Anders Sunesen of Lund who asked what should be done with clerics who were so violent that they could not safely be placed in monasteries. Innocent instructed that bishops must place them in secure detention (sub arcta custodia detinere, qui, quum sint incorrigibiles, nec in monasteriis valeant custodiri), "since it is in the public interest that crimes do not remain unpunished. ${ }^{99}$ On the question of their capture, laymen who acted on instructions from bishops in the arrest of such men did not incur the sanction of the canon, but could seize them, even violently, and convey them to (ecclesiastical) judgment, as long as it was at the command of prelates, to whose jurisdiction the punishment of criminous clerics belonged, and the violence was proportionate to the resistance offered. ${ }^{100}$ The solution in Denmark, as indeed it was in contemporary England, was close collaboration between the lay power and the Church in the apprehension and punishment of dangerous clerics: secular coercive power was harnessed to the disciplinary authority of the Church, but bishops bore the burden of providing the secure detention deemed necessary.

There remained the problem of renegade clerics who claimed immunity. In 1213, Count Ferdinand of Flanders and the dowager Countess Matilda complained to Innocent III about men who cut their hair and claimed clerical privilege when they were arrested for crimes, even though nothing in their earlier dress or occupation suggested that they were clerics. Writing to the three Flemish bishops (Thérouanne, Arras, Tournai), Innocent quoted the ancient adage that "he who abuses the power entrusted to him deserves to lose the privilege «, ${ }^{101}$ reinforced by a favourite maxim of his own, that "he who breaks the law invokes its aid in vain «, ${ }^{102}$ and ordered, that »if, after three warnings, such men refuse to mend their ways, they should be excluded from the immunity established for the protection of clerics and control of lay violence. $\ll^{103}$

99 et publicae utilitatis intersit, ne crimina remaneant impunita: Ut famae tuae, 10 Dec. 1203: 3 Comp. 5.21.8; X 5.38.35; Reg. vi. 181(183). On the maxim, publicae utilitatis intersit, see Fraher, Theoretical Justification. Misled by the erroneous address to 'London< in $X$, Fraher saw links with the Becket controversy. The maxim was used again in the Sorrento case in 1213: PL, ccxvi, 928-931 (Reg. xvi. 139), at 929.

100 et ad iudicium trahere possunt, si oporteat, etiam violenter, dum tamen id de mandato faciant praelatorum, quorum illi sunt iurisdictioni subiecti [...] dum tamen non amplius eorum violentia se extendat, quam defensio vel rebellio potius exigit clericorum.

101 Above, n. 55.

102 Liber Extra, ed. Friedberg, 5.39.45: Frustra legis auxilium invocat qui comittit in legem. For earlier use, see PL, ccxiv, 965; ccxv, 207, 633; ccxvi, 241; for probable Roman antecedants: Codex Iustinianus, ed. Krueger, 4.4.37§1 and 6.30.22§12.

103 Liber Extra, ed. Friedberg, 5.39.45: volumus et mandamus, ut tales, si tertio a te commoniti se ipsos contempserint emendare, illius efficiantur immunitatis extorres, quae pro clericorum tutela et laicorum violentia coercenda dignoscitur instituta. 
The story of clerical exemption is typical of the way in which theoretical principles were progressively refined in the eighty years following Gratian's completion of the Decretum c.1141-1145, through a process of repeated consultation between regional prelates and the papacy. ${ }^{104}$ Confronted by the realities of life outside the classroom, broad statements of clerical privilege and exemption gave way to recognition that outrageous behaviour, or out and out apostasy, undermined the privileges conferred by religious profession and ordination. As early as 1146 Eugenius III had instructed an English bishop to withdraw the protection of Si quis suadente from men who had abandoned their calling, and his successors were prepared to do likewise, as long as the Church retained the right to maintain or withhold the privilege.

104 Duggan, Making Law or Not?, esp. 64-65. 


\section{References}

\section{Primary sources}

Appendix concilii Lateranensis: Concilia omnia tam generalia quam particularia ..., ed. Petrus Crabbe (2nd edition), (Cologne, 1551) ii, 820-944; repr. in Mansi, xxii, 248-453.

Authenticum. Novellarum constitutionum Iustiniani versio vulgata, ed. Gustav Haenel (Leipzig, 1851; repr. Aalen, 1974).

Codex Theodosianus, ed. Paul Krueger (Berlin, 1923-1926).

Collectio Belverensis: Oxford Bodleian e Mus. 249 (S.C. 27835), fols 121r-125r.

Corpus iuris canonici, ed. Emil Friedberg, 2 vols. (Leipzig, 1879-1881).

Codex Iustinianus, in Corpus iuris civilis, ed. Krueger, vol. 2.

Corpus iuris civilis, ed. Paul Krueger, Theodor Mommsen, Rudolf Schoell and Wilhelm Kroll, 3 vols. (Berlin, 1905-1929; repr. 1954).

Councils and Synods, with other Documents relating to the English Church, vol. 2, A.D. 1205-1313, ed. Frederick Maurice Powicke and Christopher Robert Cheney (Oxford, 1981).

Epistolae pontificum Romanorum ineditae, ed. Samuel Loewenfeld (Leipzig, 1885).

John of Salisbury, Policraticus, PL, cxc, 379-822.

Justinian's Institutes, trans. Peter Birks and Grant McLeod (with the Latin text of Paul Krueger) (Ithaca, New York, 1987); cf. Joseph A. C. Thomas, The Institutes of Justinian, Text, Translation and Commentary (Amsterdam, 1975).

Lateran Councils: Conciliorum oecumenicorum decreta, ed. Giuseppe Alberigo, Klaus Ganzer, A Carcía y García, F Lauritzen and Alberto Melloni (3rd edition), (Bologna, 1973); the same text, with the same pagination, with an English translation: Decrees of the Ecumenical Councils, ed. Norman P. Tanner, 2 vols. (Georgetown, 1990).

Letters of John of Salisbury, i: The Early Letters, ed. and trans. W. J. Millor Harold E. Butler and Christopher Nugent Lawrence Brooke, Nelson's Medieval Texts (London, 1955; reissued Oxford, 1986); ii: The Later Letters (1163-1180), ed. and trans. William J. Millor and Christopher Nugent Lawrence Brooke, OMT (Oxford, 1979).

Liber Extra: Decretales Gregorii IX, ed. Emil Friedberg, Corpus iuris canonici, ii.

Literae Cantuarienses. The Letter Book of the Monastery of Christ Church Canterbury, ed. Joseph Brigstocke Sheppard, 3 vols., RS 85 (London, 1886).

London Trailbaston Trials, ed. Ralph B. Pugh (London, 1975).

Mediae Latinitatis lexicon minus, ed. Jan Frederik Niermeyer; Co van de Kieft; Jan W. J. Burgers (Leiden, 2002).

Novellae constitutiones, in Corpus iuris civilis, iii.

Rufinus, Historia Ecclesiastica, PL, xxi; trans. Philip R. Amidon, S. J., The Church History of Rufinus of Aquileia, Books 10 and 11 (Oxford, 1997).

Selected Letters of Pope Innocent III concerning England, ed. Christopher R. Cheney and William H. Semple, Nelsons Medieval Texts (London, 1953).

Summa decretorum des Magister Rufinus, ed. Heinrich Singer (Paderborn, 1902; repr. 1963). Wiltshire Gaol Delivery and Trailbaston Trials 1275-1306, ed. Ralph B. Pugh (Devizes, 1978). 


\section{Secondary sources}

Arabello, Carlo, `Nulli credimus esse incognitum`: un messale Veronese ed un inedito di Eugenio III, Aevum 66 (1992) 233-244.

Berger, Adolf, Encyclopedic Dictionary of Roman Law (New York, 1931; repr. 1991).

Berkhofer, Robert F., Guerno the Forger and his Confession, Anglo-Norman Studies 36 (2013) 53-68.

Berkhofer, Robert F., Forgery and Pope Alexander III's Decretal Scripta autentica, in: John Witte, Jr, Sara McDougall and’Anna di Robilant (eds.), Texts and Contexts in Legal History. Essays in Honor of Charles Donahue (Berkeley, CA 2016) 95-111.

Brett, Martin and Somerville, Robert, The transmission of the councils from 1130 to 1139, in: John Doran and Damian J. Smith (eds.), Pope Innocent II (1130-1143). The World vs. the City (London, 2016) 226-271.

Duggan, Anne J., Thomas Becket (London, 2004).

Duggan, Anne J., Making the Old Law `New<, I. Problems of Authority and Interpretation in Gratian's Decretum, in: Szabolcs Anzelm Szuromi (ed.), Medieval Canon Law Collections and European Ius commune (Középkori kánonjogi gyüjtemények és az európai ius commune) (Budapest, 2006) 207-235.

Duggan, Anne J., Manu sollicitudinis: Celestine III and Canon Law, in: John Doran and Damian Smith (eds.), Pope Celestine III (1191-1198). Diplomat and Pastor (Farnham, 2008) 189-235.

Duggan, Anne J., Roman, Canon, and Common Law in Twelfth-Century England: The Council of Northampton (1164) Re-Examined, Historical Research 83 (2010) 379-408.

Duggan, Anne J., Making Law or Not? The Function of Papal Decretals in the Twelfth Century, in: Peter Erdő and Szabolcs Anzelm Szuromi (eds.), Proceedings of the Thirteenth International Congress of Medieval Canon Law, Esztergom 2008 (Vatican City, 2010) 41-70.

Duggan, Charles, The Becket Dispute and the Criminous Clerks, Bulletin of the Institute of Historical Research 35 (1962) 1-28; repr. in Charles Duggan, Medieval Canon Law in England, Variorum Reprints, CS 151 (London, 1982) no. X.

Duggan, Charles, Improba pestis falsitatis: Forgeries and the Problem of Forgery in TwelfthCentury Decretal Letters (with special reference to English cases), in: Horst Fuhrmann (ed.), Fälschungen im Mittelalter, ii, 319-361; repr. in Duggan, Decretals and >New Law<, no. VIII.

Duggan, Charles, Decretal Letters to Hungary, Folia Theologica 3 (Budapest, 1992) 5-31; repr. in Charles Duggan, Decretals and >New Law', no. V.

Duggan, Charles, Decretals and the Creation of the sNew Law in the Twelfth Century: Judges, Judgements, Equity and Law, Ashgate Variorum, CS 607 (Aldershot, 1998).

Falkenstein, Ludwig, Die Sirmondsche Sammlung der 56 Litterae Alexanders III, in: Rudolf Hiestand (ed.), Hundert Jahre Papsturkundenforschung. Bilanz-MethodenPerspektiven (Abhandlungen der Akademie der Wissenschaften zu Göttingen. Philologisch-Historische Klasse, 3rd Ser. 261; Göttingen, 2003) 267-334.

Fraher, Richard M., The Theoretical Justification for the New Criminal Law of the High Middle Ages: srei publicae interest, ne crimina remaneant impunitar, University of Illinois Law Review 3 (1984) 577-595.

Fried, Johannes, Donation of Constantine and Constitutum Constantini (Berlin, 2007).

Fuhrmann, Horst, Einfluss und Verbreitung der pseudo-isidorischen Fälschungen, 3 vols., Schriften der MGH, 24 (Munich, 1972-1974).

Fuhrmann, Horst, The Pseudo-Isidorian Forgeries, in: Jasper and Fuhrmann, Papal Letters, 135-195. 
Gaudemet, Jean, La formation du droit séculier et du droit de l'église aux IVe et au Ve siècles (Paris, 1957).

Gouron, André, Sur les sources civilistes et la datation des Sommes de Rufin et d'Etienne de Tournai, Bulletin of Medieval Canon Law ns 16 (1986) 55-70; repr. in Droit et coutume en France aux XIIe et XIIIe siécles (Aldershot, 1993) no. X.

Green, Judith A., The Government of England under Henry I (Cambridge, 1986).

Helmholz, Richard H., The Ius Commune in England: Four Studies (Oxford, 2001).

Helmholz, Richard H., The Oxford History of the Laws of England, vol. 1, The Canon Law and Ecclesiastical Jurisdiction from 597 to the 1640 s (Oxford, 2004).

Herde, Peter, Römisches und kanonistisches Recht bei der Verfolgung des Fälschungen im Mittelalter, Traditio 21 (1965) 291-362.

Holtzmann, Walther, Krone und Kirche in Norwegen im 12. Jahrhundert, Deutsches Archiv 2 (1938) 341-400.

Holtzmann, Walther, La »Collectio Seguntina« et les décrétales de Clément III et de Célestin III, Revue d'histoire ecclésiastique 50 (1955) 400-453.

Jasper, Detlev, The Beginning of the Decretal Tradition, in: Jasper and Fuhrmann, Papal Letters, 7-81.

Jasper, Detlev and Fuhrmann, Horst, Papal Letters in the Early Middle Ages (Washington DC, 2001).

Knibbs, Eric, The Interpolated Hispana and the Origins of Pseudo-Isidore, Zeitschrift der Savigny-Stiftung für Rechtsgeschichte, Kanonistische Abteilung, 130/99 (2013) 1-71.

Landau, Peter, Ursprünge und Entwicklung des Verbotes doppelter Strafverfolgung wegen desselben Verbrechens in der Geschichte des kanonischen Rechts, Zeitschrift der Savigny-Stiftung für Rechtsgeschichte, Kanonistische Abteilung, 66 (1970) 124-156.

Maitland, Frederic W., Roman Canon Law in the Church of England (London, 1898).

Morey, Adrian and Brooke, Christopher N. L., Gilbert Foliot and his Letters (Cambridge, 1965).

Pennington, Kenneth, The Biography of Gratian, the Father of Canon Law, Villanova Law Review, lix (2014) 679-706.

Pugh, Ralph B., Imprisonment in Medieval England (Cambridge, 1968).

Richter, Joachim, Stufen pseudoisidorischer Verfälschung: Untersuchungen zum Konzilsteil der pseudoisidorischen Dekretalen, Zeitschrift der Savigny-Stiftung für Rechtsgeschichte, Kanonistische Abteilung 64 (1978) 1-72.

Schieffer, Rudolf, Die Zeit des karolingischen Großreichs (714-887) (Stuttgart, 2005).

Stubbs, William, Select Charters and other Illustrations of English Constitutional History (9th revised Edition), (Oxford, 1913).

van Caenegem, Ralph C., English Lawsuits from William I to Richard I, vol. II: Henry II and Richard I (London, 1991).

Wei, John, The Later Development of Gratian's Decretum, in: Joseph Goering, Stephan Dusil and Andreas Thier (eds.), Proceedings of the Fourteenth International Congress of Medieval Canon Law, Toronto, 5-11 August 2012, Monumenta Iuris Canonici, Series C: Subsidia, 15 (Città del Vaticano, 2016) 149-161.

Winroth, Anders, The Making of Gratian's Decretum (Cambridge 2000).

Winroth, Anders, Where Gratian Slept: The Life and Death of the Father of Canon Law, Zeitschrift für Rechtsgeschichte Kanonistische Abteilung, cxxx/xcix (2013) 105-128.

Zechiel-Eckes, Klaus, Ein Blick in Pseudoisidors Werkstatt: Studien zum Entstehungsprozeß der falschen Dekretalen mit einem exemplarischen editorischen Anhang, Francia 28 (2001) 37-90. 
Zechiel-Eckes, Klaus, Auf Pseudoisidors Spur, oder: Versuch einen dichten Schleier zu lüften, in: Wilfried Hartmann and Gerhard Schmitz (eds.), Fortschritt durch Fälschungen? Ursprung, Gestalt und Wirkungen der pseudoisidorischen Fälschungen. Beiträge zum gleichnamigen Symposium an der Universität Tübingen vom 27. und 28. Juli 2001, MGH, Studien und Texte 31 (Hanover, 2002) 1-28.

Zechiel-Eckes, Klaus, Fälschung als Mittel politischer Auseinandersetzung: Ludwig der Fromme (814-840) und die Genese der pseudoisidorischen Dekretalen, Nordrhein-Westfälische Akademie der Wissenschaften und der Künste - Vorträge: Geisteswissenschaften 428 (Paderborn, 2011).

Zutshi, Patrick, Innocent III and the Reform of the Papal Chancery, in: Andrea Sommerlechner (ed.), Innocenzo III. Urbs et Orbis, Atti del Congresso Internazionale Roma, 9-15 settembre 1998, vol. 1 (Rome, 2003) 84-101. 